\title{
SENCAR Mouse
}

National Cancer Institute

\section{Source}

National Cancer Institute. SENCAR Mouse. NCI Thesaurus. Code C14314.

A mouse strain that was selectively bred to be highly susceptible to agents and

procedures that induce carcinogenesis, primarily skin carcinogenesis; these mice have a low incidence of spontaneous tumor formation. 